\title{
In pursuit of control: involving suppliers of critical technologies in new product development
}

\author{
Lisa Melander, David Rosell and Nicolette Lakemond
}

\section{Linköping University Post Print}

\section{Tweet}

N.B.: When citing this work, cite the original article.

Original Publication:

Lisa Melander, David Rosell and Nicolette Lakemond, In pursuit of control: involving suppliers of critical technologies in new product development, 2014, Supply chain management, (19), 56, 722-732.

http://dx.doi.org/10.1108/SCM-01-2014-0040

Copyright: Emerald Group Publishing Limited http://www.emeraldinsight.com/

Postprint available at: Linköping University Electronic Press

http://urn.kb.se/resolve?urn=urn:nbn:se:liu:diva-103938 


\title{
In pursuit of control: involving suppliers of critical technologies in new product development
}

\begin{abstract}
Purpose - The purpose of this paper is to explore the dynamics of management and control in collaborations with suppliers of critical technology.

Design/methodology/approach - Three collaborative product development projects at a system integrator in the Telecom industry were studied. The data was collected through 22 semi-structured interviews and a workshop at the studied company and its suppliers.

Findings - The paper shows that in situations of high dependence on suppliers of critical technologies, control may be pursued by complementing black box development with appropriate checks and balances in the collaboration, i.e. by using combinations of control mechanisms, disconnected development and joint problem solving, contracts and trust, and alignment efforts on project and strategic levels. Further, the paper demonstrates that this involves several trade-offs related to the advantages of increased monitoring and disadvantages of decreased levels of freedom for the supplier and consequently decreased prerequisites for supplier creativity.

Research limitations/implications - The qualitative approach of the research limits generalizability. Our study is limited to three projects at one firm.

Practical implications - Technological roadmaps can be used as an important tool to facilitate alignment with suppliers of critical technologies. Limited influence on project level can be supported by influencing the supplier on a strategic level. By collaborating on a strategic level, firms can gain alignment for future projects and diminish the need for direct project control within the projects. Long-term collaborations facilitate control in projects with powerful suppliers of critical technologies.
\end{abstract}

Originality/value - While many studies suggest simplified responses to complex situations of supplier involvement in product development, this study provides insight into the complex responses to control suppliers of critical technologies.

Key words New product development, Supplier involvement, Control, Goal alignment Paper type Case study 


\section{Introduction}

New product development (NPD) literature has shown that large firms increasingly tend to rely on external collaborations in product development (Hagedoorn and Schakenraad 1994; Hagedoorn 2002). Although many firms have a considerable internal knowledge base, advances in technology development and increasing product complexity are important driving forces to involve suppliers of complementary technologies in NPD (Grant and Baden-Fuller 2004). A vast body of literature shows that supplier involvement in NPD is positively related to NPD performance (Johnsen 2009). However, much of this research is based on the involvement of manufacturing suppliers who complement the buying firm's technology mainly with manufacturing knowledge. In contrast, this paper focuses specifically on suppliers of critical technologies, which have been recognized as being important sources of innovation (Cuervo-Cazurra and Un 2010). By collaborating with these suppliers, firms can achieve not only incremental innovations, such as process improvements, but also radical innovations, by implementing new technology (Soosay et al. 2008). In this paper, these suppliers are referred to as technology suppliers. In the relationships between buyers and technology suppliers, the buying firm is dependent on the supplier's knowledge of a technology that is new to the buying firm. Consequently, the information between the buyer and the supplier is asymmetrically distributed (Mishra et al. 1998).

It has been argued that the problems related to information asymmetry in cooperative relationships such as between buyers and suppliers can be studied using an agency perspective (1989). Buyer - supplier relationships represent an agency situation, where the principal (the buyer) normally has a desire to control the agent (the supplier). Recommendations in existing literature are often based on the buying firm being in control, or at least based on situations in which buying firms are able to gain control (Clark and Fujimoto 1991; Wasti and Liker 1999). In relationships with technology suppliers, the buying firms have limited knowledge of the new technologies provided by the suppliers, limited influence on and control over the detailed specifications, and often need to rely on black box development (Clark, 1989). At the same time, buying firms are highly dependent on technology suppliers, as they provide critical technologies. Buying firms are therefore inclined to control the activities of technology suppliers, but have limited possibilities to do so. This complicates the management of potential opportunistic behavior (cf. Grandori 2001), and suggests that collaboration cannot rely on mainly relational aspects such as trust and long-term relationships, which are stressed in the existing literature on supplier involvement in NPD (Hoegl and Wagner 2005; Lockström et al. 2010; Petersen et al. 2005). Until now, there has been limited insight into what buying firms can do to gain control in these situations. Therefore, the purpose of this paper is to refine existing theories on collaboration between suppliers and buyers in NPD by exploring the dynamics of control in buyer relationships with technology suppliers in NPD collaborations.

\section{Theoretical background}

NPD projects aim to generate new products, and can involve a number of contacts with external parties (Arranz and Fernández de Arroyabe 2006). Several benefits have been associated with the involvement of suppliers in NPD. These include lower costs, faster 
introduction to the market (Chen et al. 2010; Labro 2006), access to new technology and access to knowledge (Ragatz et al. 1997b). It has also been shown that it is sometimes difficult to capitalize on these benefits in NPD projects (Wagner and Hoegl 2006). Some studies have even shown negative effects or no effect at all when suppliers are involved in NPD (Hartley et al. 1997; von Corswant and Tunälv 2002). A recent study showed that collaborations with suppliers did not in any way contribute to firms' innovativeness ( $\mathrm{Su}$ et al. 2009). Consequently, supplier involvement in NPD represents a complex situation.

Agency theory has been proposed as a useful perspective from which to study the problems related to principle - agent structures (Eisenhardt 1989). Agency theory considers principalagent relationships where the principal delegates work to the agent. It has been argued that agency theory is most relevant in situations in which there is a substantial goal conflict, such as in buyer - supplier relationships, a degree of uncertainty in new product development situations, and situations in which the evaluation of behaviors is difficult due to a high degree of information asymmetry (Eisenhardt, 1989). Despite its potential, a recent review shows that there has been scarce use of agency theory in the supply chain literature (Fayezi et al. 2012). Agency problems involve issues such as goal alignment (Eisenhardt 1989), different forms of controlling the agent, through monitoring (Rijsdijk and van den Ende 2011), contracts, and trust (Blomqvist et al. 2005).

Problems related to principal - agent structures are particularly prevalent when technology suppliers are involved. As these suppliers provide specialized or unique resources to a buying firm (Nair et al. 2011), and buying firms have only limited knowledge regarding these technologies, it is not always possible to control the activities of the suppliers. Buying firms may, however, be inclined to be in control as technology suppliers provide critical technologies to the NPD project. Gaining control in these situations can be a challenging task. Contracts are control mechanisms that can be used to increase control in inter-firm relationships. Contracts can be used to specify responsibilities, to limit the spreading of information, to agree on cost-sharing and on the specification of exclusivity periods and so on (Baldwin 2008). Contracts are a means of controlling the supplier and are easy to refer to if conflicts arise (Mayer and Teece 2008). As a complement to contracts, firms can develop trust as a mechanism for control (Arranz and Arroyabe 2011; Blomqvist et al. 2005; Gulati 1995; Poppo and Zenger 2002). One benefit of combining contracts and trust in buyer-supplier relationships is that opportunism can be better mitigated than when contract and trust are used separately (Liu et al. 2009). As for trust, it has been widely studied in buyer-supplier collaborations (Blomqvist et al. 2005; Bunduchi 2013; Hernández-Espallardo et al. 2010). Das and Teng (1998) argue that control and trust are not independent concepts. Typically, the level of trust in a relationship tends to vary with the control mechanisms that are used. Rijsdijk and van den Ende (2011) propose a classification of control mechanisms based on monitoring that can be used in collaborative buyer-supplier relationships in NPD: (i) output monitoring, (ii) process monitoring and (iii) socialization. When using output control, buying firms focus on monitoring and evaluating the desired outputs of the activities of the suppliers. In black box development, the output standards are often represented in the functional specifications. Generally, output monitoring is combined with a disconnected way of working, based on a clear task division between a buyer and a supplier (Lakemond et al. 2006), based on measuring the results of supplier activities in terms of delivery time, quality and product 
functionality. In contrast, process monitoring does not specifically focus on the output, but rather on how this output is achieved. This involves monitoring the agent's behavior and processes. Usually, this is achieved through a more integrated way of working (Lakemond et al. 2006). The monitoring of the behavior and processes of a supplier involves a cost. When costs of monitoring are high, an outcome-based monitoring is to be preferred, but where costs are acceptable, a behavior-based monitoring approach could be more efficient (Eisenhardt 1989). In addition to output monitoring and process monitoring, monitoring through socialization has been emphasized. This socialization does not emphasize the activities or output, but represents a socialization process among individuals and orienting agents towards organizational goals (Aulakh and Gencturk 2000).

It has been argued that more monitoring is not always better (Jacobides and Croson 2001) and does not necessarily increase the agent's alignment with the principal's goals (Tosi et al. 1997). Moreover, close monitoring may have negative effects on an agent when it perceives a loss of independence and experiences distrust on the part of the principal (van der Valk and van Iwaarden 2011). In situations of high dependency on suppliers, these suppliers can easily mitigate a buying firm's monitoring activities (Heide et al. 2007).

In addition to contracts, trust and monitoring, goal alignment can work as an assurance against opportunism in buyer-supplier relationships (Jap 1999). By developing goal alignment in collaborative projects, firms can achieve compatible objectives even though the buying firm may have preferences that are not aligned with the supplier's original preferences. On a project level, it is important to agree from the outset on the objectives of a collaborative project, so that firms can strive towards a shared goal. Several studies point to the importance of reaching alignment within the supply chain in NPD (Khan et al. 2012; Pero et al. 2010).

It has been suggested that efforts on a strategic level can complement and facilitate the control of supplier activities on an NPD project level. Top management support has been found to be an important success factor in supplier involvement in NPD (Ragatz et al. 1997a), which can facilitate alignment of the firms' interests on a strategic level (Johnsen et al. 2009). Technology roadmaps can be used as important tools to connect innovation strategies with sourcing strategies (Schiele 2010). They provide a long-term vision to help firms with strategic decisions (Phaal et al. 2004) and can be used as a tool for communicating technology, product and market perspectives. It is not uncommon for firms to use several types of technological roadmaps (Lee and Park 2005). In collaborative NPD, technology roadmaps can be shared between participating firms to show their long-term planning (Handfield and Lawson 2007; van Echtelt et al. 2008). Moreover, it has been demonstrated that a powerful buyer's technology roadmap can influence the supplier's technology roadmap (McIvor et al. 2006). Some warrants are, however, necessary. Sharing knowledge through technology roadmaps may encourage opportunistic behavior which could lead to diminished trust in the collaboration (Petrick and Echols 2004).

When possible, managers prefer to achieve control by having a dominant position in a joint decision-making process (Kim and Oh 2005). In collaborations with technology suppliers, however, buying firms may not necessarily have a dominant position. Consequently, they may pursue control in different ways, by making use of the project level as well as the strategic level. Contracts and monitoring in NPD can be regarded as project level control mechanisms, as they are usually related to specific NPD projects. Technology roadmaps concern long-term 
perspectives on technology development and are consequently strategic control mechanisms. Trust and goal alignment can be established on a project as well as a strategic level between the decision makers at the respective firms. This is supported by studies that indicate that transfer of information facilitates the development of trust in the supply chain (Pérez and Sánchez 2001). Control may thus be pursued on different levels as well as through different mechanisms. This is summarized in figure 1, which provides an overview of the concepts used in this paper.

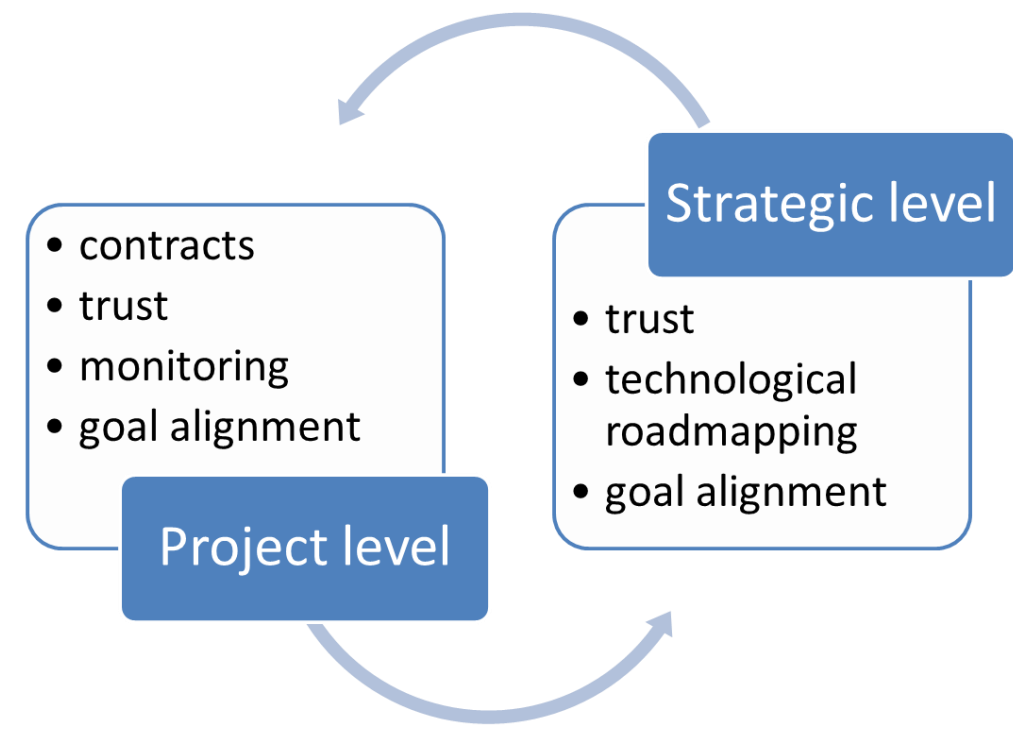

Figure 1 Control on a project and strategic level

\section{Research Method}

High-tech industries operate at the cutting edge of technology development, which does not always reside in-house (Grant and Baden-Fuller 2004). Therefore, in order to study control in buyer-supplier relationships where suppliers are experts in a certain field of technology, a firm in the Telecom industry was selected. The Telecom industry is dynamic and highly competitive, and the pace of technology development is high. The firm in this study is the market leader in this industry and supplies complex systems and solutions to Telecom operators. The firm, which we refer to as Telefirm, has a long track record of technology and product development and has more than 30,000 patents. Sixteen new patents are applied for every day. The number of $R \& D$ employees amounts to approximately 20,000. Consequently, the firm has a very strong internal NPD capability. Despite this strong internal NPD capability, Telefirm has collaborated with suppliers in NPD for decades and has long experience of collaboration with suppliers. For this reason, the firm was chosen as a suitable illustration (Siggelkow 2007) of complex product development collaborations with powerful suppliers. Telefirm can be described as a large systems integrator which relies on complementary knowledge that resides at these specialized and technically capable suppliers.

In the initial phase of the study, three meetings were conducted with Telefirm's strategic management. In these meetings, the objective of this study and possible projects for investigation were discussed. The case selection was information-oriented (Flyvbjerg 2004) 
and consequently information-rich cases (Patton 2002: 230) were selected. Projects were selected that were strategically important to Telefirm, in areas where the suppliers contributed with important complementary technology knowledge. Technologies that needed to be integrated were new to Telefirm and also, to some extent, to industry. In order to execute the projects, Telefirm relied heavily on external suppliers providing the technology. The projects thus represent a typical agency situation with information asymmetry as an important precedent for the inter-firm collaboration. In order to exclude the effects and benefits of longterm relationships with suppliers, the projects selected were those in which Telefirm had many years of personal relationships with its suppliers, which it is argued is necessary for developing trust (Poppo and Zenger 2002). Therefore, only projects where the firms had collaborated for a longer period of time and had thus experienced a certain degree of alignment were included. To ensure that the cases had rich information, Telefirm and the research team actively participated in the sampling process which resulted in the selection of three projects.

Data collection relied mainly on interviews, but additional secondary data was gathered from project documents, company policies, and general company and branch information. For each project, several key respondents were identified in order to include a variety of perspectives and allow for triangulation. Respondents were individuals who were directly involved in the projects. Hence, knowledgeable informants who view the phenomenon from diverse competencies were interviewed (Eisenhardt and Graebner 2007). Individuals with similar functional responsibilities were interviewed in all the projects. These included project managers, R\&D managers, sourcing and supply managers, and strategic product managers. An interview guide was developed to allow flexibility and allow for follow-up questions to be asked in a semi-structured way.

The majority of the interviews were conducted face-to-face. On the few occasions when this was not possible, interviews were conducted by telephone. In total, 22 interviews were conducted, with each interview lasting between 45 and 90 minutes. The interviews were conducted between November 2011 and May 2012. Ten individuals were interviewed In the Antenna project, six individuals were interviewed in the Converter project and there were six respondents in the Processor project. The studies of the Antenna and Processor projects are based on the views of both Telefirm and the suppliers. However, the Converter study relies only on the perespectives of Telefirm, as it was not possible to interview the supplier due to the fact that sensitive negotiations were being conducted between Telefirm and the supplier. All the interviews were recorded, transcribed and sent to the respondent for reviewing and possible clarification.

The data analysis focused on core situations, such as problematic situations in the project. These were identified and interpreted. Furthermore, within-case analysis in detailed case descriptions were written in which the respondents' views of important episodes were presented. The data was systematically structured and analysed. The analytical dimensions for our constructs, goal alignment and control, were developed from the literature and used in the analysis. Triangulation was ensured by using multiple sources of data, including people with different roles and who represented different functions, as well as, when possible, the supplier's view. Furthermore, company documents were studied to confirm interview results. A chain of evidence was followed, and we provided Telefirm with case descriptions and 
presented our findings at a workshop where seven individuals from Telefirm participated. During the workshop, we had the opportunity to discuss and validate our interpretation of the projects. With regard to external validity, we used replication for the sampling of respondents. Finally, we studied relevant literature and searched the literature for additional explanations. We used case study protocols and a case study database (Yin 2009) to ensure reliability. The database contains the raw data as well as the transcripts, structured analyses and case writeups. For each of our constructs, we identified a number of dimensions that helped to explain the constructs. For example, regarding goal alignment, we investigated the firms' desire to cooperate, the length of the relationships, attempts to align goals, how problems were solved and which were the conflicts of interests. These dimensions were compared in the cross-case analysis.

\section{The three cases}

Telefirm is a world-leading high-technology telecom company with more than 100,000 employees world-wide. In the dynamic and rapidly changing Telecom industry, innovation is important. The three NPD projects represent collaborations with external suppliers, who contribute with technology expertise to the development of a new system or component in the projects. These suppliers are trusted to develop their parts based on functional performance requirements from Telefirm, similar to black box development (Clark 1989). Consequently, the collaboration was based on a task division which allowed each firm to concentrate primarily on certain specified and disconnected tasks in the development (cf. Lakemond et al. 2006). However, some aspects in the development could be characterized as joint and integrated problem solving.

The Antenna project focuses on developing a completely new product, i.e. an antenna, on a system level, while the other two cases concerned the development of a new generation of components: a converter and a processor. The supplier in the Antenna project is here referred to as Supplier 1. In the Converter project, two competing suppliers were involved; they are referred to here as Supplier 2 and Supplier 3, while the supplier in the Processor project is called Supplier 4. Different project teams and individuals at Telefirm were involved in the projects, but had similar responsibilities. Key data on the firms involved in the cases is shown in Table 1. As can be seen in Table 1, the suppliers have a relatively high R\&D expenditure, which supports the argument that they are suppliers who provide new technology to the NPD projects.

Table 1 Key data of Telefirm and its suppliers (from 2012).

\begin{tabular}{|c|c|c|c|c|c|}
\hline & Telefirm & Supplier 1 & Supplier 2 & Supplier 3 & Supplier 4 \\
\hline No. of employees & 104,500 & 6,700 & 34,600 & 9,200 & 82,500 \\
\hline Sales M EUR & 25,213 & 1,323 & 11,515 & 2,270 & 41,000 \\
\hline $\begin{array}{l}\text { R\&D spending as } \% \text { of } \\
\text { revenue }\end{array}$ & $13 \%$ & $10 \%$ & $14 \%$ & $17 \%$ & $15 \%$ \\
\hline $\begin{array}{l}\text { Previous generations } \\
\text { of NPD involving the } \\
\text { supplier }\end{array}$ & N.A & 0 & 4 & 4 & 2 \\
\hline Project duration & N.A & 2 years & 2 years & 2 years & 2 years \\
\hline
\end{tabular}


In all three projects, Telefirm used contractual agreements with the suppliers. The contractual information is displayed in Table 2. Non-Disclosure Agreements (NDA) or Confidential Agreements (CA) refer to contracts between two firms that outline confidential material, knowledge, or information that the firms wish to share but to which at the same time they wish to restrict access by third parties. In addition, Intellectual Property (IP) rights refer to situations where Telefirm was open with information that was patented. In this study, a Development Agreement is an agreement (contract) regarding cooperation and a division of responsibilities between the firms involved in the NPD process. Finally, by Purchasing Agreement (PA) we mean a legal document that outlines the terms and conditions connected with a transaction of the developed item.

To ensure that technology and sensitive information would not be spread beyond the project team, the firms used NDAs and CAs, and relied on IP. Even though the firms used contracts, trust was identified as an important factor in order for the NPD to make progress. The senior vice president at one of the suppliers explained how the development started: "The key factor was trust. We could have blocked each other, as we had huge portfolios on each side to build upon. But we decided to start the collaboration with a hand shake." Once the collaboration had been initiated, the negotiation of contractual agreements started.

Table 2 Contractual information.

\begin{tabular}{llll}
\hline & Antenna project & Converter project & Processor project \\
\hline NDA, CA & Yes & Yes & Yes \\
Relying on IP & Yes & Yes & Yes \\
Development agreement & Yes, developed from general & No & No \\
& PA & & \\
Purchasing agreements & Yes & Yes, mainly price & Yes, mainly price \\
& & negotiations & negotiations \\
\hline
\end{tabular}

\subsection{Antenna Project}

This collaborative NPD project concerned an innovative product that combined two existing technologies, radio and antenna, and the goal was to merge them into one product. Hence, it was a new concept that is new to the firms and to the industry. The product is intended for the mobile operator market and has the benefits of lower power consumption and faster installation time, and can also introduce new technologies and frequency bands. This product was designed to handle the increasing demands on the mobile broadband, with regard to both speed and coverage from mobile users. In the design phase, the firms held workshops for two days every second week in which ten individuals participated, five from each firm. As the project progressed, the project team continued to meet every four to six weeks. Challenges, such as those related to organization, administration, market or time, were shared between the firms.

In order to better understand the other party, the firms presented and discussed their technology roadmaps with each other. The roadmaps contained information about the firms' outlook on future technologies and market expectations. The R\&D manager at the supplier explained how the technological roadmaps facilitated the collaboration: "We realized that 
Supplier 1 and Telefirm had a shared view on strategy and on $R \& D$ along with our technology roadmaps." The project was prioritized at both firms and even though the commercialization of the product had not started, discussions about the next generation were already underway.

The development agreement was based on a general purchasing agreement between the firms. This contract was a means for Telefirm to have control over the development activities of the supplier. The buying firm's sourcing manager pointed out: "From my point of view, we don't let go of the control. We enhance it in contracts and are much tougher than when we simply buy a product. In that way it's a better control, but can we trust them?" It was important for Telefirm to have a close collaboration and to work in an integrated manner, in order to gain insight into the supplier's development. By having transparency, it was possible to create a contract that would push the supplier to perform at a specific level. According to the supplier's manager, however, the contract was not sufficient to gain control in the project. The trust that existed between the firms was more important: "To be honest, this couldn't work if we only tried to rely on the contract." Consequently, the projects relied on both contracts and trust, and trust was especially important at the beginning of the collaboration in combination with confidentiality agreements. A development agreement was not formulated until a later stage in the project.

\subsection{Converter Project}

The Converter project was part of the development of Telefirm's $5^{\text {th }}$ generation of a radio base platform. One of the critical components in this platform is the analog-digital converter. This device converts analog input to digital output and sets the bandwidth of the receiver. The goal was to create a converter that has both improved capacity and an improved cost structure in comparison with the previous generation. For each new generation, Telefirm makes a tentative specification of requirements which is sent to Supplier 2 and Supplier 3. For this particular product, the suppliers were eager to participate in NPD with Telefirm, which is the market leader in the industry. Control took place through monitoring the activities of the suppliers. Meetings took place about once a month. In addition, there were weekly telephone calls to see how far the suppliers had progressed. The development was clearly divided between Telefirm and its suppliers, and the organizations were separated. The two suppliers shared the total volume of converters to Telefirm. However, the supplier who had the best overall solution was selected to deliver a larger part of that volume. The outcome of the project was that both suppliers managed to create converters according to Telefirm's performance requirements.

The supplier collaborations had a long-term perspective, as the next generation of the product is being conceptualized before the previous generation has been completed. The firms have their technology roadmaps as tools for when they describe their view of the future of the technology development. The suppliers shared their roadmaps with Telefirm, who in turn provided the suppliers with insight into its own technology roadmap. The firms also discussed technology development in the short term, as the suppliers continuously update Telefirm on their technology progress. Telefirm did not disclose all the details of its technology roadmap with the suppliers. In particular, Telefirm was restrictive in sharing system knowledge with the suppliers. This was explained by one of Telefirm's managers as: "We don't want to reveal 
our systems to a supplier. That's how spies put together a puzzle, so it's up to us to give them as few pieces as possible." Some problems have arisen in situations when the supplier wanted to know more than was necessary. As one manager at Telefirm explained: "They ask all types of questions; they ask us 'why do you want a double in and output?' That's our business; you don't need to know the benefit of that. We had those relationship problems for a while." Telefirm experienced that these types of questions emerged specifically when the supplier's system engineers were at the meetings with Telefirm. Telefirm handled this by allowing only those engineers whose work was directly related to the component, and not the supplier's system engineers, to take part in these meetings.

In the Converter project, there are no development agreements between the firms. Instead, Telefirm and the suppliers relied on confidentiality agreements and protection by patents. In general, the development consists of Telefirm providing performance requirements to the suppliers and then following up on the progress that they make. As described by Telefirm's R\&D manager: "We contact the supplier and then take the role of monitoring what's going on." Despite Telefirm's limited role in monitoring, the suppliers tended to follow Telefirm's suggestions to the letter, and thereby strengthen Telefirm's control. This could be a challenge for Telefirm, as one manager explained: "They listen a lot to us and that way they might take the wrong track. They often do exactly what we tell them to and then they choose that solution even if there might be a better one. They choose the track we have pointed to and don't look at other options." Hence, there may be additional technical solutions that the suppliers do not investigate.

\subsection{Processor Project}

Telefirm relies on its own unique computer platform, where one critical component is the processor which is supplied by Supplier 4. The platforms are delivered to several of Telefirm's internal subsidiaries, which have different demands on these computers. Requirements include aspects of capacity, size, encryption and cost. For Telefirm, the goal is that the processor has all the desired features. For Supplier 4, the goal was to gain feedback on the processor from Telefirm in order to improve it before it becomes available on the market.

The dialog with Supplier 4 mainly took place by telephone and email between one development engineer at Telefirm and one contact person at the supplier. This contact person forwarded technical issues to other development engineers within the supplier's organization. There were weekly telephone calls between these two individuals in which the communication was of a technical nature and problem reports were presented. When there were major technical issues, Telefirm's R\&D engineers went to the supplier for a few days of problem solving. Commercial issues were handled outside the NPD project team. The key account manager at the supplier and the purchaser at Telefirm met to discuss contracts and prices. The supplier was trusted to develop the processor and the organizations were separated in the NPD project. The outcome of the project was a processor which contained several, but not all, of Telefirm's desired features.

Both Telefirm and Supplier 4 are very competitive in their respective industries, but Telefirm is not one of the major customers of the supplier. However, the collaboration between the firms stretched further than the NPD project. The firms had technology exchange discussions where they discussed how the technology might evolve over a ten-year period. In 
this forum, the technology roadmaps were important tools for demonstrating the firms' longterm commitment to different technologies. Even if product development is important, one manager at the supplier described how the strategic forums are more important: "We do big business with Telefirm, but Supplier 4 will not go under if we lose that deal. But the strategic value of collaborating with Telefirm is far more important." The strategic collaboration is called the Technology Alignment Program and consists of top technical managers from both firms.

The collaboration between the firms was limited. As Telefirm's project manager expressed: "Supplier 4 provides us with a design that we can test early. There is a lot of debugging, the collaboration really isn't more than that." Despite the limited collaboration and limited opportunities for Telefirm to have insight into the work of Supplier 4, the supplier found that it was important to maintain open communication with Telefirm. A manager at the supplier described problem solving as follows: "It's important to have a process where the customer is close so we can tell them what is happening and what we are doing to solve it." Consequently, although it was expressed that a high degree of communication was desirable, the project seemed to rely on limited information sharing.

\section{Analysis and Discussion}

\subsection{Having Control of the Product Development}

In contrast to alignment, control, in terms of monitoring and the use of contracts, was mainly a concern on the project level. The role of trust as a control mechanism was used both on project level and strategic level, and was found to be important for the long-term collaboration and agreement on future projects. All the suppliers in the study provided expertise to the projects and were trusted to develop specific parts. These parts were critical for the final product and made a significant contribution to the functionality of Telefirm's customer offering. There is a situation of information asymmetry as Telefirm lacks specific knowledge of the components and technologies developed. The development could be characterized as black box development based on functional performance requirements. Hence, although there was a high degree of dependence, there were limited prerequisites for Telefirm to achieve process control.

Our study highlights three difficulties related to process control: control and monitoring ability, control and trust, and control and creativity. The first difficulty concerns the balance between gaining monitoring abilities without actually controlling the supplier. According to theory (Rijsdijk and van den Ende 2011), process control is usually preferred when there is collaboration between the supplier and buyer and the monitoring ability is high since behaviors and mechanisms are monitored and evaluated. This was demonstrated in our projects through transparency, visibility, monitoring what was going on and discussions. Monitoring ability was an important factor that influenced Telefirm's possible options for controlling the projects. In the projects studied, the monitoring ability varied. Supplier control through monitoring was more easily accomplished in the Antenna and the Converter projects than in the Processor project due to the frequency of meetings and to the fact that some problems were solved jointly. In the Converter project, Telefirm requested insight into the supplying firm, but at the same time knew that the supplier was capable of running its own 
development. Hence, visibility to be able to design a contract that would push the supplier to perform its best while at the same time allowing that supplier the freedom to do what it does better became a matter of balance.

The second balance evolved around the fear of knowledge spillovers. Through monitoring by participating at meetings, Telefirm wanted to control what was going on in the supplier's part of the project. However, involving themselves in the suppliers' development also carries the risk that the buying firm reveals more about its systems than was originally intended. Hence, as described previously in the literature (Das and Teng 1998), Telefirm needed to find a balance between control and trust. As in social and clan control, Telefirm employed monitoring in combination with trust. Telefirm trusted Supplier 2 and Supplier 3 despite their concern about spies. Monitoring and trust can be used as complementary mechanisms to control collaborations (Arranz and Arroyabe 2011; Blomqvist et al. 2005; Gulati 1995; Poppo and Zenger 2002). The third balance concerned creativity. Control, particularly in the Converter project, was believed to have hampered the suppliers' creativity in trying different technologies to implement into the development. Research suggests that limiting information hampers product innovation and creativity (Carson 2007). Another mechanism that limited creativity was the usage of contracts, as some aspects were specified in the contracts and thus limited the suppliers' options.

In the Antenna project, Telefirm implemented tougher contracts, but the contract in itself was not sufficient to control Supplier 1. The limitations of contracts were confirmed in all three projects studied. Since contracts were not sufficient to control the suppliers, Telefirm used trust as a complement to contracts. This is in line with previous research that has argued that contracts and relational mechanisms (norms and trust) complement each other in R\&D collaborations (Arranz and Arroyabe 2011; Gulati 1995; Liu et al. 2009). However, in the collaborative projects, contracts were necessary to enable technical information to be shared within the project. NDA and protection through IP allowed for sensitive technology to be discussed, and thus better designs could be made and problems solved more easily. Table 3 shows a summary of our findings from the three case studies.

Table 3 Findings

\begin{tabular}{lccc}
\hline & $\begin{array}{c}\text { Considerations on } \\
\text { project level }\end{array}$ & $\begin{array}{c}\text { Considerations on } \\
\text { strategic level }\end{array}$ & $\begin{array}{c}\text { Interaction: project and } \\
\text { strategic level }\end{array}$ \\
\hline Monitoring & $\mathrm{x}$ & & \\
Contracts & $\mathrm{x}$ & $\mathrm{X}$ & $\mathrm{x}$ \\
Technological roadmapping & $\mathrm{x}$ & $\mathrm{X}$ & $\mathrm{x}$ \\
Goal alignment & $\mathrm{x}$ & $\mathrm{x}$ & $\mathrm{x}$ \\
Trust & $\mathrm{x}$ & & \\
\hline
\end{tabular}

\subsection{Reaching Goal Alignment in the Product Development}

Previous research has shown that rich prior experience of buying firms results in greater exposure to various possible integrations with different partners (Wang 2011). By building long-term relationships with key suppliers, firms' capabilities can be aligned not only on a project level but also on a strategic level, facilitating future projects (van Echtelt et al. 2008). Similar evidence was found in our study, during which future technology developments were 
discussed with the suppliers. In particular, the results show that project and strategic level controls are intertwined in collaborations with technologically capable suppliers and situations of information asymmetry. Technology roadmaps were used as a strategic tool to enable the firms to understand the future direction of each other's development, and as an operational tool at project level. Technological roadmaps were not only used for sharing information and gaining control, but also for achieving future technology alignment. Previous studies have also suggested that benefits can be captured when technology roadmaps are aligned with suppliers (McDermott and Handfield 2000; van Echtelt et al. 2008). This can be difficult and may take years to achieve (van Echtelt et al. 2008). We show that this technology alignment is supported by a process of close collaboration in NPD projects. In the Antenna project and the Converter project, a disconnected way of working was complemented by regular joint problem solving and discussions about the next generation of the products developed. The necessity of, but also the opportunities for, technology alignment was highly dependent on the length of the relationships. Long-term relationships allowed the firms to gradually reach a higher degree of goal alignment, not only in the actual NPD project, but also for future generation of developments of the products under study.

The situation in the Processor project was somewhat different. In this project, there was limited goal alignment and, for the most part, Supplier 4 controlled the development of the component. Supplier 4 is very dominant on the market and does not allow Telefirm to influence its development. However, the firms have reached goal alignment on a strategic level through a joint Technology Alignment Program where top management from the Telefirm and Supplier 4 meet and discuss future directions of the technology development. These discussions do not involve discussions about the on-going project, but cover many technologies and products. The forum is used to discuss the development of the industry as a whole. In fact, Telefirm had limited opportunities to influence the development of the component during the NPD project. However, technology roadmaps were used to share information on a strategic level. Hence, there was limited collaboration and goal alignment on a project level. Instead, alignment was aimed for on a strategic level based on a longer-term perspective. Consequently, our findings extend previous findings on aspects of long-term and short-term collaboration (van Echtelt et al. 2008) by showing the importance of strategic alignment for achieving project alignment between firms and demonstrating the role of technology roadmaps in the alignment process.

Figure 2 illustrates our findings of the use of different mechanisms on strategic and project level. It is clear that complementary mechanisms are necessary when collaborating with suppliers of critical technologies in NPD. On strategic level, the control mechanisms are essentially limited to trust, as other control mechanisms, such as contracts, are difficult to formulate and implement under these circumstances of complexities and technological uncertainties. In addition, technology roadmaps are used on strategic level in order to communicate future needs and align goals. On project level, different forms of monitoring, such as output and process control, can be implemented depending on the level of integration in the projects. Contracts, including IP rights and NDAs, are used to enable knowledge sharing. Here, trust is needed as a complementary control mechanism. As has been discussed, technology roadmaps are used on project level in order to reach goal alignment. However, this alignment is more efficient in a long-term collaboration. 
Figure 2 Illustration of control and goal alignment on strategic and project level

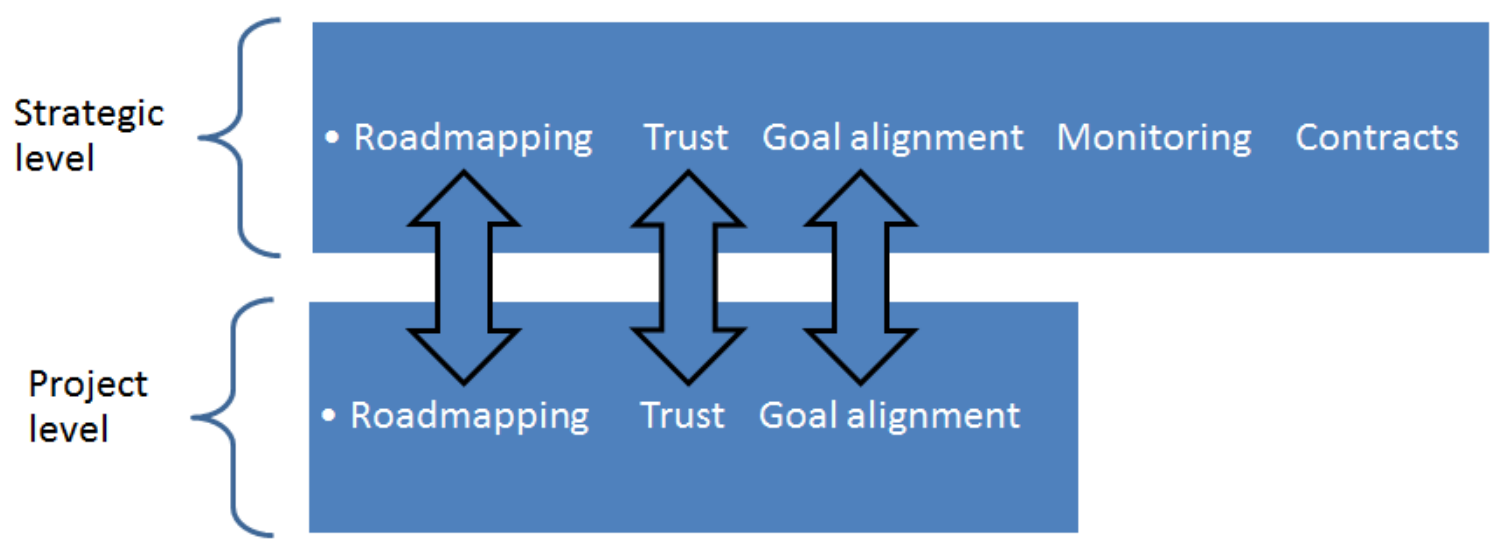

\section{Conclusions}

Our results show that the collaboration with suppliers of critical technologies in NPD projects represents a complex situation of simultaneous high dependency, information asymmetry and consequentially limited possibilities to achieve control.

Previous studies have described black box development as situations in which buying firms provide functional performance specification to suppliers (Clark 1989; Petersen et al. 2005). These situations have been connected to limited product system task dependencies and a disconnected way of working (Lakemond et al. 2006). Accordingly, recommendations to manage these collaboration are based on output monitoring rather than process monitoring (Rijsdijk and van den Ende 2011). In contrast, our cases of collaboration with suppliers of critical technology represent a high degree of dependency in terms of product functionality and adherence to time schedules, and seem to require appropriate checks and balances in the collaboration with suppliers. In pursuit of control, firms may complement output control with process control, use black box and disconnected development in combination with regular joint problem solving, use contracts and trust simultaneously, and perform alignment efforts on project as well as on strategic levels. In addition, the study points to the importance of technological roadmaps as a mechanism not only on a strategic level but also on project level (cf. van Echtelt et al. 2008).

In the pursuit of control, firms need to consider several possible dilemmas. First, the use of process monitoring can increase control, but too much monitoring can limit the supplier's level of freedom. The study shows that process monitoring can influence creativity, where our finding is supported by previous studies (Carson 2007). Second, control needs to be balanced with trust, an important prerequisite in all three projects in our study and also supported by evidence in previous research (Blomqvist et al. 2005).

The study points to several managerial implications for firms that need to collaborate with technology suppliers. First, on a project level, firms need to consider a combination of contracts, trust, monitoring, and goal alignment through the use of technology roadmaps in order to gain control over the suppliers' activities. Output monitoring can be complemented 
by process monitoring, but too much process monitoring can constrain the creativity output of the supplier. Second, in situations of high degrees of asymmetry, it may be difficult to gain control only through project level mechanisms. In these situations, strategic level control mechanisms can be a useful, and sometimes the only, way to increase control over the supplier's activities.

While previous studies have indicated the complementarity contracts and trust (Poppo and Zenger 2002), this study indicates the use of multi-level control mechanisms, and the importance of strategic control mechanisms when project control is difficult to achieve. The dynamic interplay between several different control mechanisms on project and strategic levels warrants further research. 


\section{References}

Arranz, N. and Fernández de Arroyabe, JC (2006), "Joint R\&D projects: Experiences in the context of European technology policy", Technological Forecasting and Social Change, Vol. 73 No. 7, pp. 860-85.

Arranz, N. and Arroyabe, JC (2011), "Effect of Formal Contracts, Relational Norms and Trust on Performance of Joint Research and Development Projects", British Journal of Management, Vol. 23 No., pp. 575-88.

Aulakh, P.S. and Gencturk, E.F. (2000), "International principal-agent relationships: Control, governance and performance", Industrial Marketing Management, Vol. 29 No. 6, pp. 521-38.

Baldwin, C.Y. (2008), "Where do transactions come from? Modularity, transactions, and the boundaries of firms", Industrial and Corporate Change, Vol. 17 No. 1, pp. 155-95.

Blomqvist, K., Hurmelinna, P., and Seppanen, R. (2005), "Playing the collaboration game right--balancing trust and contracting", Technovation, Vol. 25 No. 5, pp. 497-504.

Bunduchi, Raluca (2013), "Trust, partner selection and innovation outcome in collaborative new product development", Production planning \& control, Vol. No. ahead-of-print, pp. 1-13.

Carson, Stephen J (2007), "When to give up control of outsourced new product development", Journal of Marketing, Vol. 71 No. 1, pp. 49-66.

Chen, J., Damanpour, F., and Reilly, R.R. (2010), "Understanding antecedents of new product development speed: A meta-analysis", Journal of Operations Management, Vol. 28 No. 1, pp. 17-33.

Clark, Kim B and Fujimoto, Takahiro (1991), Product development performance: Strategy, organization, and management in the world auto industry: Harvard Business Press

Clark, Kim B. (1989), "Project Scope and Project Performance: The Effect of Parts Strategy and Supplier Involvement on Product Development", Management Science, Vol. 35 No. 10, pp. 1247-63.

Cuervo-Cazurra, A. and Un, C. A. (2010), "Why Some Firms Never Invest in Formal R\&D", Strategic Management Journal, Vol. 31 No. 7, pp. 759-79.

Das, Tarun K and Teng, Bing-Sheng (1998), "Between trust and control: Developing confidence in partner cooperation in alliances", Academy of management review, Vol. No., pp. 491-512.

Eisenhardt and Graebner (2007), "Theory building from cases: Opportunities and challenges", Academy of management journal, Vol. 50 No. 1, pp. 25-32.

Eisenhardt, K.M. (1989), "Agency theory: An assessment and review", Academy of management review, Vol. 14 No. 1, pp. 57-74.

Fayezi, Sajad, O'Loughlin, Andrew, and Zutshi, Ambika (2012), "Agency theory and supply chain management: a structured literature review", Supply Chain Management: An International Journal, Vol. 17 No. 5, pp. 556-70.

Flyvbjerg, B [2004], "Five misunderstandings about case-study research", in C. Gobo Seale, G. Gubrium, JF Silverman, D. (ed.), Qualitative research practice (London: Sage Publications Ltd), 420-34.

Grandori, A. (2001), "Neither hierarchy nor identity: knowledge-governance mechanisms and the theory of the firm", Journal of management and Governance, Vol. 5 No. 3, pp. 381-99.

Grant, Robert M. and Baden-Fuller, Charles (2004), "A Knowledge Accessing Theory of Strategic Alliances", Journal of Management Studies, Vol. 41 No. 1, pp. 61-84. 
Gulati, R. (1995), "Does familiarity breed trust? The implications of repeated ties for contractual choice in alliances", Academy of management journal, Vol. 38 No. 1, pp. 85-112.

Hagedoorn, J and Schakenraad, J (1994), "The effect of strategic technology alliances on company performance", Strategic Management Journal, Vol. 15 No. 4, pp. 291-309.

Hagedoorn, J. (2002), "Inter-firm R\&D partnerships: an overview of major trends and patterns since 1960", Research Policy, Vol. 31 No. 4, pp. 477-92.

Handfield, R.B. and Lawson, B. (2007), "Integrating suppliers into new product development", Research-Technology Management, Vol. 50 No. 5, pp. 44-51.

Hartley, JL, Zirger, BJ, and Kamath, RR (1997), "Managing the buyer-supplier interface for on-time performance in product development", Journal of Operations Management, Vol. 15 No. 1, pp. 57-70.

Heide, J.B., Wathne, K.H., and Rokkan, A.I. (2007), "Interfirm monitoring, social contracts, and relationship outcomes", Journal of marketing Research, Vol. 44 No. 3, pp. 425-33.

Hernández-Espallardo, Miguel, Rodríguez-Orejuela, Augusto, and Sánchez-Pérez, Manuel (2010), "Inter-organizational governance, learning and performance in supply chains", Supply Chain Management: An International Journal, Vol. 15 No. 2, pp. 101-14.

Hoegl, M. and Wagner, S.M. (2005), "Buyer-supplier collaboration in product development projects", Journal of Management, Vol. 31 No. 4, pp. 530.

Jacobides, M.G. and Croson, D.C. (2001), "Information policy: Shaping the value of agency relationships", Academy of management review, Vol. 26 No. 2, pp. 202-23.

Jap, S.D. (1999), "Pie-expansion efforts: collaboration processes in buyer-supplier relationships", Journal of marketing Research, Vol. 36 No. 4, pp. 461-75.

Johnsen, Thomas, Howard, Mickey, and Miemczyk, Joe (2009), "UK defence change and the impact on supply relationships", Supply Chain Management: An International Journal, Vol. 14 No. 4, pp. 270-79.

Johnsen, Thomas E. (2009), "Supplier involvement in new product development and innovation: Taking stock and looking to the future", Journal of Purchasing and Supply Management, Vol. 15 No. 3, pp. 187-97.

Khan, Omera, Christopher, Martin, and Creazza, Alessandro (2012), "Aligning product design with the supply chain: a case study", Supply Chain Management: An International Journal, Vol. 17 No. 3, pp. 323-36.

Kim, Bowon and Oh, Heungshik (2005), "The impact of decision-making sharing between supplier and manufacturer on their collaboration performance", Supply Chain Management: An International Journal, Vol. 10 No. 3, pp. 223-36.

Labro, Eva (2006), "Is a focus on collaborative product development warranted from a cost commitment perspective?", Supply Chain Management: An International Journal, Vol. 11 No. 6, pp. 503-09.

Lakemond, N., Berggren, C., and Weele, A. (2006), "Coordinating supplier involvement in product development projects: a differentiated coordination typology", $R \& D$ Management, Vol. 36 No. 1, pp. 55.

Lee, S. and Park, Y. (2005), "Customization of technology roadmaps according to roadmapping purposes: Overall process and detailed modules", Technological Forecasting and Social Change, Vol. 72 No. 5, pp. 567-83.

Liu, Y., Luo, Y., and Liu, T. (2009), "Governing buyer-supplier relationships through transactional and relational mechanisms: Evidence from China", Journal of Operations Management, Vol. 27 No. 4, pp. 294-309.

Lockström, M., et al. (2010), "Antecedents to supplier integration in the automotive industry: A multiple-case study of foreign subsidiaries in China", Journal of Operations Management, Vol. 28 No. 3, pp. 240-56. 
Mayer, K.J. and Teece, D.J. (2008), "Unpacking strategic alliances: The structure and purpose of alliance versus supplier relationships", Journal of Economic Behavior \& Organization, Vol. 66 No. 1, pp. 106-27.

McDermott, C. and Handfield, R. (2000), "Concurrent development and strategic outsourcing: Do the rules change in breakthrough innovation?", The Journal of High Technology Management Research, Vol. 11 No. 1, pp. 35-57.

McIvor, R., Humphreys, P., and Cadden, T. (2006), "Supplier involvement in product development in the electronics industry: a case study", Journal of Engineering and Technology Management, Vol. 23 No. 4, pp. 374-97.

Mishra, D.P., Heide, J.B., and Cort, S.G. (1998), "Information asymmetry and levels of agency relationships", Journal of marketing Research, Vol. 35 No. 3, pp. 277-95.

Nair, Anand, Narasimhan, Ram, and Bendoly, Elliot (2011), "Coopetitive Buyer-Supplier Relationship: An Investigation of Bargaining Power, Relational Context, and Investment Strategies", Decision Sciences, Vol. 42 No. 1, pp. 93-127.

Patton, M.Q. (2002), Qualitative research and evaluation methods, California: Thousand Oaks, CA: Sage Publications.

Pérez, Manuela P and Sánchez, Angel M (2001), "Supplier relations and flexibility in the Spanish automotive industry", Supply Chain Management: An International Journal, Vol. 6 No. 1, pp. 29-38.

Pero, M., et al. (2010), "A framework for the alignment of new product development and supply chains", Supply Chain Management: An International Journal, Vol. 15 No. 2, pp. 115-28.

Petersen, KJ, Handfield, RB, and Ragatz, GL (2005), "Supplier integration into new product development: coordinating product, process and supply chain design", Journal of Operations Management, Vol. 23 No. 3-4, pp. 371-88.

Petrick, I.J. and Echols, A.E. (2004), "Technology roadmapping in review: A tool for making sustainable new product development decisions", Technological Forecasting and Social Change, Vol. 71 No. 1, pp. 81-100.

Phaal, R., Farrukh, C.J.P., and Probert, D.R. (2004), "Technology roadmapping-A planning framework for evolution and revolution", Technological Forecasting and Social Change, Vol. 71 No. 1, pp. 5-26.

Poppo, L. and Zenger, T. (2002), "Do formal contracts and relational governance function as substitutes or complements?", Strategic Management Journal, Vol. 23 No. 8, pp. 70725.

Ragatz, G. L., Handfield, R. B., and Scannell, T. V. (1997a), "Success factors for integrating suppliers into new product development", Journal of Product Innovation Management, Vol. 14 No. 3, pp. 190-202.

Ragatz, GL, Handfield, RB, and Scannell, TV (1997b), "Success factors for integrating suppliers into new product development", Journal of Product Innovation Management, Vol. 14 No. 3, pp. 190-202.

Rijsdijk, Serge A. and van den Ende, Jan (2011), "Control Combinations in New Product Development Projects*", Journal of Product Innovation Management, Vol. 28 No. 6, pp. 868-80.

Schiele, Holger (2010), "Early supplier integration: the dual role of purchasing in new product development", $R \& D$ Management, Vol. 40 No. 2, pp. 138-53.

Siggelkow, N. (2007), "Persuasion with case studies", The Academy of Management Journal Vol. 50 No. 1, pp. 20-24.

Soosay, C.A., Hyland, P.W., and Ferrer, M. (2008), "Supply chain collaboration: capabilities for continuous innovation", Supply Chain Management: An International Journal, Vol. 13 No. 2, pp. 160-69. 
Su, Y.S., Tsang, E.W.K., and Peng, M.W. (2009), "How do internal capabilities and external partnerships affect innovativeness?", Asia Pacific Journal of Management, Vol. 26 No. 2, pp. 309-31.

Tosi, H.L., Katz, J.P., and Gomez-Mejia, L.R. (1997), "Disaggregating the agency contract: The effects of monitoring, incentive alignment, and term in office on agent decision making", Academy of management journal, Vol. 40 No. 3, pp. 584-602.

Wagner, S.M. and Hoegl, M. (2006), "Involving suppliers in product development: Insights from R\&D directors and project managers", Industrial Marketing Management, Vol. 35 No. 8, pp. 936-43.

van der Valk, Wendy and van Iwaarden, Jos (2011), "Monitoring in service triads consisting of buyers, subcontractors and end customers", Journal of Purchasing and Supply Management, Vol. 17 No. 3, pp. 198-206.

van Echtelt, Ferrie E. A., et al. (2008), "Managing Supplier Involvement in New Product Development: A Multiple-Case Study", Journal of Product Innovation Management, Vol. 25 No. 2, pp. 180-201.

Wang, C.H. (2011), "The moderating role of power asymmetry on the relationships between alliance and innovative performance in the high-tech industry", Technological Forecasting and Social Change, Vol. 78 No. 7, pp. 1268-79.

Wasti, S.N. and Liker, J.K. (1999), "Collaborating with suppliers in product development: a US and Japan comparative study", Engineering Management, IEEE Transactions on, Vol. 46 No. 4, pp. 444-60.

von Corswant, Fredrik and Tunälv, Claes (2002), "Coordinating customers and proactive suppliers: A case study of supplier collaboration in product development", Journal of Engineering and Technology Management, Vol. 19 No. 3-4, pp. 249-61.

Yin, Robert K. (2009), Case study research: design and methods, Los Angeles, Calif.: Sage Publications 